\title{
Phytochemical Content, Radical Scavenging Ability \& Enzyme Inhibiting Activities of Selected Spices (Cinnamon, Cardamom and Cloves)
}

\author{
Nigel Chimbetete, Martha Verghese, Rajitha Sunkara, Lloyd T. Walker \\ Food and Animal Science Department, Alabama A \& M University, Normal, AL, USA \\ Email: martha.verghese@aamu.edu
}

How to cite this paper: Chimbetete, N., Verghese, M., Sunkara, R. and Walker, L.T. (2019) Phytochemical Content, Radical Scavenging Ability \& Enzyme Inhibiting Activities of Selected Spices (Cinnamon, Cardamom and Cloves). Food and Nutrition Sciences, 10, 266-275.

https://doi.org/10.4236/fns.2019.103020

Received: November 22, 2017

Accepted: March 10, 2019

Published: March 13, 2019

Copyright $\odot 2019$ by author(s) and Scientific Research Publishing Inc. This work is licensed under the Creative Commons Attribution International License (CC BY 4.0).

http://creativecommons.org/licenses/by/4.0/

\section{Open Access}

\begin{abstract}
Cinnamon, cardamom and cloves have been widely used for medicinal purposes as well as essential cooking ingredients for flavor. The objective of the research was to investigate the antioxidant content, antioxidant capacity, and inhibition of lipid and carbohydrate metabolizing enzyme activities of selected spices (cinnamon, cardamom \& cloves) methanol (ME) and water extracts (WE). The phytochemical content was determined by total phenolic and total flavanoid content. The antioxidant potential was determined by measuring 2,2-Diphenyl-1-picrylhydrazyl (DPPH) radical scavenging activity and Ferric Reducing Antioxidant Power (FRAP) in spice's (ME) and (WE) extracts. Total phenolic (GAE mg/100g dry weight) and flavonoid (mg CE/100g dry weight) content were the highest in Cloves (ME) 174.4 and 101.06. The lowest values for phenolic content were seen in ME and WE of Cardamom at 31.24 and 7.55. The DPPH IC50 values ranged from $0.22 \mathrm{mg} / \mathrm{mL}$ (Cloves ME) to $0.60 \mathrm{mg} / \mathrm{mL}$ (Cardamom ME). FRAP ( $\mu \mathrm{mol} \mathrm{Fe}{ }^{2+} / 100 \mathrm{~g}$ dry weight) for Cinnamon, Cardamom (ME) was 2438.5 and 325 . Clove (ME) had a significantly higher reducing potential of 6888.5 which might have been attributed by the high amounts of phenolics and flavonoids in the spice. FRAP in spice extracts (WE) was lower with values of 2296.5 and 218.5 and 2310.5, respectively. The highest inhibition of the $\alpha$-glucosidase was observed by Clove (ME) $86.5 \%$, which also had the highest amylase enzyme inhibition at $71 \%$. However, inhibition of the lipase enzyme was highest by the Cinnamon (WE) extracts $44.3 \%$. The potential of phytochemicals in spices was studied and if consumed in high amounts could offer antioxidative properties and regulate key digestive enzymes which may lead to prevention or decreased progression of diseases such as Cancer, Diabetes and Cardiovascular diseases.
\end{abstract}




\section{Keywords}

Phytochemicals, Cardamom, Cinnamon, Cloves, Carbohydrate Metabolizing Enzymes

\section{Introduction}

The risk of developing chronic diseases such as cancer, cardiovascular diseases, diabetes mellitus and hypertension is highly prevalent in the U.S [1]. The factors which contribute to metabolic syndrome are abnormally high glucose levels, abnormally high blood pressure, large abdominal circumference, and high triglyceride levels [2]. A survey conducted by Vella and others [3] showed that the awareness of functional foods in relation to health is increasing and individuals are demanding more functional foods that offer opportunities to reduce the risk of developing chronic diseases. Toda, Kawabata \& Kasai [4] reported a-glucosidase inhibitors from clove, while research by Baker adn others suggests anticarcinogenic properties of the spice [5]. Subash and others [6] reported the effect of cinnamon by isolating the active compounds to determine the main phytochemicals responsible for the anti-diabetic mechanism. The compound cinnamaldehyde was effective in lowering the plasma glucose levels in the STZ-induced diabetic rats used in the study. Not only did cinnamaldehyde reduce the glucose levels but it also lowered serum total cholesterol, triglycerides levels, and LDL (low-density lipoprotein). The compound was also able to increase the supply of insulin and HDL (high-density lipoprotein). The production of cardamom has increased over the years especially in Vietnam since 1990 because of its biological benefits as well as a high demand for the spice in the development of food products [7]. Wojdyło, Oszmiański, \& Czemerys [8] described the various phytochemicals present in Cloves such as eugonol, acetyleugenol, chavicol, acetyl salicylate, and humulenes. In a research study conducted by Krishnaiah, Sarbatly \& Bono [9], various spices such as Indian gooseberry, omum, cumin, cardamom, betel leaf and brandy were examined for their phenolic and flavonoid contents. A medium content level (50 - $100 \mathrm{mg}$ ) was found in the products and linked to the inhibitory potential on key enzymes in the human biological system. Some parts of the world that regularly consume spices have shown to have lower numbers of chronic disease cases due to the variety in phytochemicals which have been seen to affect various metabolic pathways [10]. Research has been focused on the utilization of polyphenols as well as to increase their consumption in a diet [11]. Cocoa beans have been reported to contain flavonoids and phenolics that may reduce reactive oxygen species (ROS). Developing chronic heart disease has been attributed to the lack of antioxidants which reduce the oxidation of LDL cholesterol [12]. Data collected by NIH, 2011 also showed that lowering LDL cholesterol reduces the risk of cardiovascular disease. The method of extraction to obtain the highest amounts of phytochem- 
icals is very crucial. A study conducted by Exteberia and others [13] indicated that extraction by supercritical carbon dioxide yielded $85 \%$ - 95\% compared to extraction by petroleum ether. A study by Thorpe \& Howard [2] reported a similar pattern showed an increase in extractability of the polyphenols in cloves using water extraction. This suggests that the characteristic of the solvent used could affect the type and amount of polyphenolic compounds extracted from the matrix of the spice.

Phytochemicals present in spices such as cinnamon and cloves, may prevent the prevalence of chronic diseases by scavenging free radicals as well as regulating pathways in the inflammation process [14]. Enzymes ( $\alpha$-amylase and $\alpha$-glucosidase) are involved in the breakdown of starch in the digestive system. The inhibition of these key digestive enzymes by phytochemicals in spices could be very effective in reducing hyperglycemia and abnormal levels of other biological constituents [15]. Therefore the objective of the research was to investigate the antioxidant content, antioxidant capacity, and inhibition of lipid and carbohydrate metabolizing enzyme (lipase activity, $\alpha$-glucosidase activity and $\alpha$-amylase) activities of selected spices (Cinnamon, Cardamom \& Cloves) methanol (ME) and water extracts (WE).

\section{Materials and Methods}

\subsection{Preparation of Cinnamon, Cardamom and Cloves Extracts}

The spices were purchased from a local store (Huntsville Alabama, USA). The three spices were ground to powdered form using the (Laboratory Blender, Warring commercial, Torrington, CT, USA). All extracts for chemical and enzymatic assays were prepared in $80 \%$ methanol and boiling water. Five grams of each spice was mixed with either $80 \%$ methanol at room temperature or water for 1 hour in a hot water bath at a temperature range of $90^{\circ} \mathrm{C}-100^{\circ} \mathrm{C}$. The supernatant was dried in Rotary Evaporator (Safe Aire, Fischer Hamilton, Gaithersburg, MD, USA). The final volume was made to $10 \mathrm{ml}$ with either solvent and stored at $-20^{\circ} \mathrm{C}$ until analysis [16].

\subsection{Determination of Total Phenolics, Flavonoids and Antioxidant Potential}

Total phenolic content was determined using the Folin Ciocalteu colorimetric method described by [17]. The results are expressed as mg GAE/100g dry weight. The total flavonoid content was determined using methods by [18]. Catechin was used as the standard and results are expressed as mg CE/100g dry weight. To determine the radical scavenging ability of the selected spices, 2,2-diphenyl-2-picrylhydrazyl (DPPH) scavenging ability was conducted using the method described by [19]. $0.1 \mathrm{mM}$ of DPPH was utilized in the sample mixture and results were expressed as IC50 of DPPH. Determination of Ferric Reducing Antioxidant Power (FRAP) assay was determined by following the method described by [20]. The samples were analyzed in triplicates and the results 
are expressed as $\mathrm{mmol} \mathrm{Fe}^{2+} / \mathrm{g}$ dry weight.

\subsection{Determination of Enzyme Inhibition of Potential}

The inhibition of pancreatic lipase (in-vitro) was measured using p-nitrophenyl butyrate (p-NPB) as a substrate as described by [21]. The reaction was started by the addition of substrate $25 \mathrm{mM}$ p-NPB in dimethylformamide (DMF). Inhibition of $\alpha$-amylase activity was carried out as described by [22]. Different concentrations of spice extracts and $\alpha$-amylase solution ( $4 \mathrm{units} / \mathrm{ml}$ ) were incubated at $25^{\circ} \mathrm{C}$ for $10 \mathrm{~min}$. After pre-incubation, $50 \mu \mathrm{l}$ of a $1 \%$ starch substrate was added to the solution to initiate the reaction. To determine the inhibition of the $\alpha$-glucosidase enzyme, the protocol as described by [23] was used. The sample was pre-incubated with phosphate buffer ( $\mathrm{pH}$ 6.9) containing $\alpha$-glucosidase solution $(1.0 \mathrm{U} / \mathrm{ml})$. After pre-incubation, $50 \mu \mathrm{l}$ of substrate p-nitrophenyl-a-dglucopyranoside solution in $0.1 \mathrm{M}$ phosphate buffer ( $\mathrm{pH}$ 6.9) was added to each well.

\section{Statistical Analysis}

All experiments were conducted in triplicates. Data was analyzed using the SAS 9.1 (2011). Means were separated using Tukey's standardized range test. Level of significance was set at $p \leq 0.05$.

\section{Results}

\subsection{Phytochemical Content in Cinnamon, Cardamom and Cloves}

The phytochemical content of selected spices cinnamon, cardamom and cloves (methanol-ME and water-WE) was shown in Table 1. The total phenolic content (TPC) (mg GAE/100g) was the lowest in (WE) and (ME) extracts of Cardamom at 7.55 and 31.24 and higher in cloves (ME) and (WE) at 174.40 $\mathrm{mg} / 100 \mathrm{~g}$ and $101.06 \mathrm{mg} / 100 \mathrm{~g}$. Methanol extractions resulted in significantly $(\mathrm{p}<$ 0.05 ) higher phenolic content (1.7 - 4 times) compared to water extraction in all spices. The total flavonoid content (TFC) (ME) was highest in cloves (ME) at $94.50 \mathrm{mg} \mathrm{CE} / 100 \mathrm{~g}$ and lowest in aqueous extracts of cardamom $(0.31 \mathrm{mg}$ $\mathrm{CE} / 100 \mathrm{~g})$.

\subsection{Reducing and Radical Scavenging Ability of Spices (Cinnamon, Cardamom and Cloves)}

The Ferric Reducing Antioxidant Potential (FRAP) and DPPH radical scavenging activity of spice extracts was determined and is shown in Table 2. Cinnamon, Cardamom, and Clove methanol extracts had higher FRAP values compared to WE. The highest FRAP was observed in Cloves ME $(6888.5 \pm 137.5$ $\left.\mu \mathrm{mol} \mathrm{Fe}^{2+} / 100 \mathrm{~g}\right)$ and a significantly $(p<0.05)$ lower FRAP was observed in Cloves WE $\left(2310.5 \pm 171.5 \mu \mathrm{mol} \mathrm{Fe}{ }^{2+} / 100 \mathrm{~g}\right)$. FRAP values for WE of Cinnamon, Cardamom and Cloves were lower (6\%,33\% and 66\%) compared to their ME. Cloves ME was able to scavenge DPPH more effectively than the other extracts 
Table 1. Phenolics and flavonoid contents of Cinnamon, Cardamom and Cloves in Methanol and Water extracts.

\begin{tabular}{ccccc}
\hline \multirow{2}{*}{ Spice } & \multicolumn{2}{c}{ Phenolics $(\mathrm{mg} \mathrm{GAE} / 100 \mathrm{~g})$} & \multicolumn{2}{c}{ Flavonoids $(\mathrm{mg} \mathrm{CE} / 100 \mathrm{~g})$} \\
\cline { 2 - 5 } & $\mathrm{ME}$ & WE & ME & WE \\
\hline Cinnamon & $154.24 \pm 0.19^{\mathrm{b}}$ & $79.20 \pm 1.1^{\mathrm{b}}$ & $63.83 \pm 0.84^{\mathrm{a}}$ & $66.69 \pm 3.67^{\mathrm{a}}$ \\
Cardamom & $31.24 \pm 0.27^{\mathrm{c}}$ & $7.55 \pm 0.17^{\mathrm{c}}$ & $6.33 \pm 0.61^{\mathrm{c}}$ & $0.31 \pm 0.10^{\mathrm{c}}$ \\
Cloves & $174.40 \pm 2.00^{\mathrm{a}}$ & $101.06 \pm 19.36^{\mathrm{a}}$ & $94.50 \pm 3.53^{\mathrm{a}}$ & $17.29 \pm 0.29^{\mathrm{b}}$ \\
\hline
\end{tabular}

ME: methanol extracts; WE: water extracts; GAE: Gallic Acid Equivalents; CE: Catechin Equivalents. Values are Mean $\pm S D ; n=3 .{ }^{\text {abc }}$ Values not sharing common superscript are significantly different $(p<0.05)$ using Tukey's studentized range test.

Table 2. Free-radical scavenging (DPPH) activity and ferric reducing antioxidant power (FRAP) of cinnamon, cardamom and cloves.

\begin{tabular}{ccc}
\hline Spice & $\begin{array}{c}\text { FRAP } \\
\left(\mu \mathrm{mol} \mathrm{Fe}{ }^{2+} / 100 \mathrm{~g}\right)\end{array}$ & $\begin{array}{c}\mathrm{DPPH} \\
\mathrm{IC}_{50}(\mathrm{mg} / \mathrm{ml})\end{array}$ \\
\hline Cinnamon ME & $2438.5 \pm 43.50^{\mathrm{b}}$ & 0.56 \\
Cinnamon WE & $2296.5 \pm 54.50^{\mathrm{b}}$ & 0.53 \\
Cardamom ME & $325.0 \pm 15.00^{\mathrm{c}}$ & 0.60 \\
Cardamom WE & $218.5 \pm 8.50^{\mathrm{c}}$ & 0.58 \\
Cloves ME & $6888.5 \pm 137.50^{\mathrm{a}}$ & 0.22 \\
Cloves WE & $2310.5 \pm 171.50^{\mathrm{b}}$ & 0.55 \\
\hline
\end{tabular}

ME: methanol extracts; WE: water extracts; DPPH: 2,2-diphenyl-1-picrylhydrazyl, FRAP: Ferric reducing antioxidant power. Values are Mean $\pm \mathrm{SD} ; \mathrm{n}=3$. ${ }^{\text {abc }}$ Values not sharing common superscript are significantly different $(p<0.05)$ using Tukey's studentized range test.

as at the lowest concentration $(0.22 \mathrm{mg} / \mathrm{ml})$, inhibition of DPPH was $62.8 \%$. An increase in percent DPPH inhibition was observed with an increase in concentration of all selected spices.

\subsection{Inhibitory Activity of Spices on Amylase Enzyme}

Inhibition of the amylase enzyme was shown in Figure 1. An increase in the concentration of both ME and WE extracts inhibited $\alpha$-amylase activity with increasing concentrations $(0.2-0.4 \mathrm{mg} / \mathrm{ml})$. The highest inhibition was seen in Cloves (ME) and (WE) at (71\%) and $65.6 \%$. Cinnamon (ME) resulted in the highest inhibition (59.5\%) of amylase activity at $0.4 \mathrm{mg} / \mathrm{ml}$ compared to Cinnamon (WE) (46.2\%). The amylase inhibition by Cardamom (ME) was over 2 fold higher compared to WE at the $0.4 \mathrm{mg} / \mathrm{ml}$ concentration, however Cardamom extracts exhibited the lowest inhibition amongst all the spices.

\subsection{Inhibitory Activity of Spices on $\alpha$-Glucosidase Enzyme}

The inhibition of $\alpha$-glucosidase activity by Cinnamon (ME and WE) is shown in Figure 2. Cloves (ME) extracts exhibited the highest inhibition at $0.4 \mathrm{mg} / \mathrm{ml}$ 


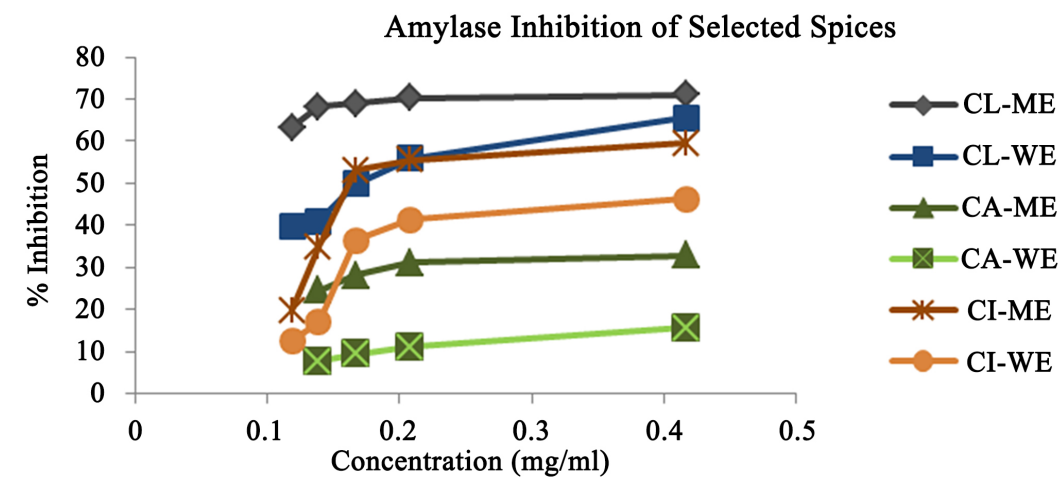

Figure 1. Amylase Inhibition of cinnamon cardamom and cloves extracts. Abbreviations: $\mathrm{CL}-$ Cloves, $\mathrm{CA}-$ Cardamom, $\mathrm{CI}-$ Cinnamon, ME-Methanol Extracts, WE-Water Extracts.

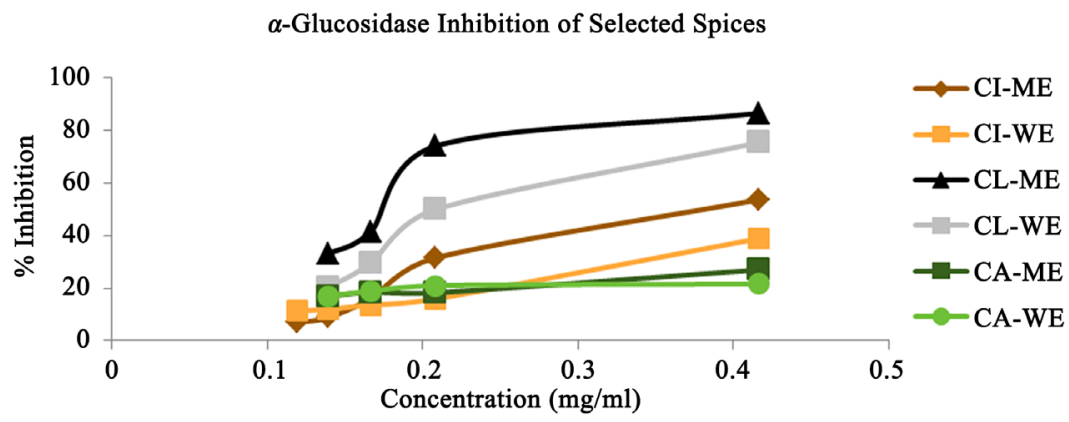

Figure 2. $\alpha$-Glucosidase Inhibition of cinnamon cardamom and cloves extracts. Abbreviations : $\mathrm{CL}-$ Cloves, $\mathrm{CA}-$ Cardamom, CI-Cinnamon, ME-Methanol Extracts, WE-Water Extracts.

(86.5\%). Cinnamon (ME) had the second highest inhibition of the enzyme at $53.6 \%$, whereas, at the same concentration $(0.4 \mathrm{mg} / \mathrm{ml})$ Cinnamon (WE) resulted in an inhibition of 38.4\%. Cardamom (ME) resulted in the highest inhibition of $\alpha$-glucosidase (26.9\%) compared to WE (21.5\%) at the same concentration $(0.4$ $\mathrm{mg} / \mathrm{ml})$.

\subsection{Inhibitory Activity of Spices on Lipase Activity}

The inhibition of lipase activity by Cinnamon (ME and WE) is shown in Figure 3. Lipase inhibition was highest at the $0.4 \mathrm{mg} / \mathrm{ml}$ concentration for all three spices. Cinnamon (WE and (ME) recorded the highest inhibition at (53.1\%) and (44.3\%) respectively. (ME) of Cardamom resulted in higher inhibition (42.7\%) of lipase as compared to Clove (ME and WE). Cloves (WE) resulted in the higher lipase inhibition (40.2\%) as compared to (ME) (34.2\%) at the highest concentration.

\section{Discussion}

The health benefits that are attributed to phytochemicals are being further researched for their effects against chronic diseases [10]. A number of phytochemicals such as catechins have been identified in cinnamon, cardamom and 


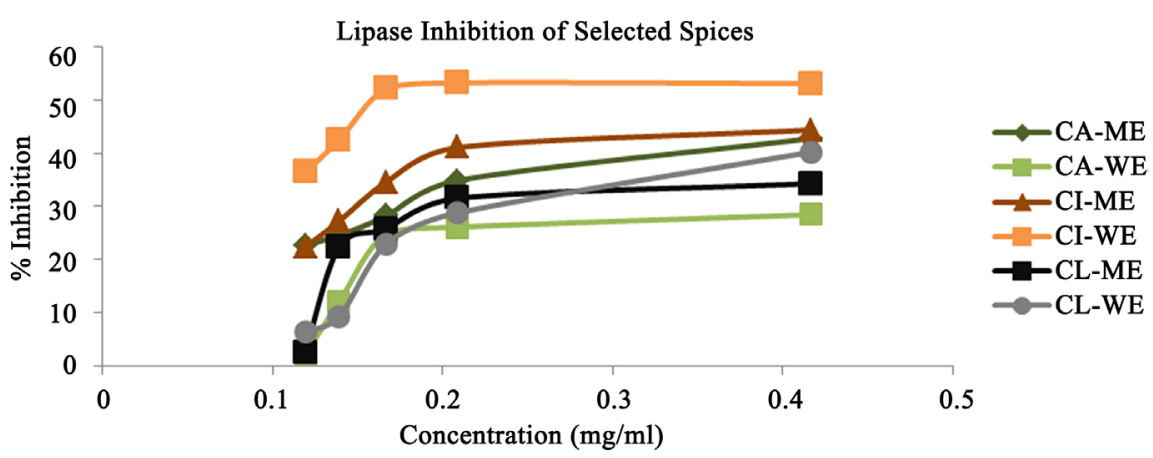

Figure 3. Lipase Inhibition of cinnamon cardamom and cloves extracts. Abbreviations: CL-Cloves, CA-Cardamom, CI-Cinnamon, ME-Methanol Extracts, WE-Water Extracts.

cloves. Research suggests these spices have cardioprotective, chemo preventive as well as anti-inflammatory effects [14].

In this study, the results showed varied extractability of phytochemicals by the use of either water or methanolic solvents. The phenolic and flavonoid content observed in Cloves ME $(174.40 \pm 2.0 \mathrm{mg} \mathrm{GAE} / 100 \mathrm{~g})$ and $(94.50 \pm 13.53 \mathrm{mg}$ $\mathrm{CE} / 100 \mathrm{~g}$ ) may be attributed to the polarity of the methanol solvent. Similar evidence in high extractability in Cloves (ME) has also been shown in research done by Hollingsworth [24]. Fruits and vegetables have been identified to contain high amounts of phytochemicals [25]. Polyphenols are known to be powerful antioxidants that have also shown the ability to scavenge free radicals in the body. The ability to scavenge free radicals can be determined by their ability to scavenge the DPPH radical [26]. A higher inhibition of DPPH by cloves could again be attributed to the amount of phytochemicals which were successfully extracted.

Another method used to determine the antioxidant power of phytochemicals is to observe the ability to reduce ferric ions to ferrous compounds. Cloves (ME) exhibited significantly higher $(\mathrm{p}<0.05)$ FRAP activity among all spices. Despite the light color of cardamom, the spice exhibited reducing and scavenging ability which may be attributed to key compounds such as linoleic acid and quercetin which act as reducers. Eugenol is one of the main chemical compounds found in Cloves that have also have been seen to exhibit high DPPH and FRAP values [27].

The inhibition of key digestive enzymes such as $\alpha$-glucosidase and $\alpha$-amylase has been identified as a potential agent to lower the incidence of diabetes [28]. Results gathered in the experiment showed an increased inhibition in a dose dependent manner $(0.1-0.4 \mathrm{mg} / \mathrm{ml})$. Cloves (ME) had a higher percent inhibition of $\alpha$-glucosidase at the highest concentration compared to Cloves WE [27]. The inhibition may have been caused by the spices decreasing the formation of a substrate-enzyme complex. The inhibition of $\alpha$-amylase by spices has been previously studied by Cazzola and others [29]. Results from the present study agree with previously published works as inhibition of $\alpha$-amylase occurred in a dose 
dependent manner. Bioactive compounds in plant materials have been attributed to the inhibition of amylase enzyme. Research by Chirumbolo [30] suggested that the bioactive compounds in fruits and vegetables attributed to the inhibition of the amylase enzyme. The inhibition of pancreatic lipase (PL) enzyme through natural bioactive compounds has attracted attention in utilizing phytochemicals as anti-obesity agents by to limiting dietary fat absorption and accumulation of lipid in adipose tissue [31].

\section{Conclusion}

Cinnamon, cardamom and cloves have been shown in various reports to have beneficial phytochemical compounds that are very important in altering the activity of digestive enzymes as well as the scavenging of free radicals that are produced in the body. They have also been used for traditional medicinal purposes to cure ailments such as colds and dental carries. The ability of the spice extracts (ME and $\mathrm{WE}$ ) to reduce ferric to ferrous and scavenge free radicals, suggests its antioxidant power. Cloves which were the darkest in color had the highest levels of phenolics and flavonoids, followed by cinnamon and finally cardamom that has a light green/yellow pigmentation. The inhibition of pancreatic lipase, $\alpha$-glucosidase, and $\alpha$-amylase activities by cinnamon, cardamom and clove extracts (ME and WE) may provide a potential means of developing safe therapeutic approaches of preventing and/or treating obesity, hyperglycemia and the metabolic syndrome.

\section{Acknowledgements}

This work was supported by the USDA National Institute of Food and Agriculture, [Evans-Allen] project [ALAX-012-0412].

\section{References}

[1] Wilper, A.P., Woolhandler, S., Lasser, K.E., McCormick, D., Bor, D.H. and Himmelstein, D.U. (2009) Hypertension, Diabetes, and Elevated Cholesterol among Insured and Uninsured US Adults. Health Affairs, 28, w1151-w1159. https://doi.org/10.1377/hlthaff.28.6.w1151

[2] Thorpe, K.E. and Howard, D.H. (2006) The Rise in Spending among Medicare Beneficiaries: The Role of Chronic Disease Prevalence and Changes in Treatment Intensity. Health Affairs, 25, w378-w388. https://doi.org/10.1377/hlthaff.25.w378

[3] Vella, M.N., Stratton, L.M., Sheeshka, J. and Duncan, A.M. (2014) Functional Food Awareness and Perceptions in Relation to Information Sources in Older Adults. Nutrition Journal, 13, 44. ttps://doi.org/10.1186/1475-2891-13-44

[4] Toda, M., Kawabata, J. and Kasai, T. (2000) $\alpha$-Glucosidase Inhibitors from Clove (Syzygium aromaticum). Bioscience, Biotechnology, and Biochemistry, 64, 294-298. https://doi.org/10.1271/bbb.64.294

[5] Zheng, G.Q., Kenny, P.M. and Lam, K.T. (1992) Sesquiterpene from Clove (Eugenia caryophyllata) as Potential Anticarcinogenic Agents. Journal of Natural Products, 55, 999-1003. https://doi.org/10.1021/np50085a029 
[6] Subash Babu, P., Prabuseenivasan, S. and Ignacimuthu, S. (2007) Cinnamaldehyde-A Potential Antidiabetic Agent. Phytomedicine, 14, 15-22. https://doi.org/10.1016/j.phymed.2006.11.005

[7] Tugault-Lafleur, C. and Turner, S. (2009) The Price of Spice: Ethnic Minority Livelihoods and Cardamom Commodity Chains in Upland Northern Vietnam. Singapore Journal of Tropical Geography, 30, 388-403. https://doi.org/10.1111/j.1467-9493.2009.00376.x

[8] Wojdyło, A., Oszmiański, J. and Czemerys, R. (2007) Antioxidant Activity and Phenolic Compounds in 32 Selected Herbs. Food Chemistry, 105, 940-949. https://doi.org/10.1016/j.foodchem.2007.04.038

[9] Krishnaiah, D., Sarbatly, R. and Bono, A. (2007) Phytochemical Antioxidants for Health and Medicine-A Move towards Nature. Biotechnology and Molecular Biology Reviews, 1, 97-104.

[10] Craig, W.J. (2009) Health Effects of Vegan Diets. The American Journal of Clinical Nutrition, 89, 1627S-1633S. https://doi.org/10.3945/ajcn.2009.26736N

[11] Ullah, M.F. and Khan, M.W. (2008) Food as Medicine: Potential Therapeutic Tendencies of Plant Derived Polyphenolic Compounds. Asian Pacific Journal of Cancer Prevention, 9, 187-196.

[12] Weisburger, J.H. (2001) Chemopreventive Effects of Cocoa Polyphenols on Chronic Diseases. Experimental Biology and Medicine, 226, 891-897. https://doi.org/10.1177/153537020122601003

[13] Etxeberria, U., de la Garza, A.L., Campión, J., Martínez, J.A. and Milagro, F.I. (2012) Antidiabetic Effects of Natural Plant Extracts via Inhibition of Carbohydrate Hydrolysis Enzymes with Emphasis on Pancreatic Alpha Amylase. Expert Opinion on Therapeutic Targets, 16, 269-297. https://doi.org/10.1517/14728222.2012.664134

[14] Baker, I., Chohan, M. and Opara, E.I. (2013) Impact of Cooking and Digestion, in Vitro, on the Antioxidant Capacity and Anti-Inflammatory Activity of Cinnamon, Clove and Nutmeg. Plant Foods for Human Nutrition, 68, 364-369. https://doi.org/10.1007/s11130-013-0379-4

[15] Adefegha, S.A. and Oboh, G. (2012) Inhibition of Key Enzymes Linked to Type 2 Diabetes and Sodium Nitroprusside-Induced Lipid Peroxidation in Rat Pancreas by Water Extractable Phytochemicals from Some Tropical Spices. Pharmaceutical Biology, 50, 857-865. https://doi.org/10.3109/13880209.2011.641022

[16] Adom, K.K. and Liu, R.H. (2002) Antioxidant Activity of Grains. Journal of Agriculture and Food Chemistry, 50, 6182-6187. https://doi.org/10.1021/jf0205099

[17] Singleton, V.L., Orthofer, R. and Lamuela-Raventós, R.M. (1999) Analysis of Total Phenols and Other Oxidation Substrates and Antioxidants by Means of Folin-Ciocalteu Reagent. Methods in Enzymology, 299, 152-178.

[18] Kim, D.O., Jeong, S.W. and Lee, C.Y. (2003) Antioxidant Capacity of Phenolic Phytochemicals from Various Cultivars of Plums. Food Chemistry, 81, 321-326. https://doi.org/10.1016/S0308-8146(02)00423-5

[19] Brand-Williams, W., Cuvelier, M.E. and Berset, C. (1995) Use of a Free Radical Method to Evaluate Antioxidant Activity. Lebensmittel-Wissenschaft und Technologie, 28, 25-30. https://doi.org/10.1016/S0023-6438(95)80008-5

[20] Benzie, I.F.F. and Strain, J.J. (1999) Ferric Reducing/Antioxidant Power Assay: Direct Measure of Total Antioxidant Activity of Biological Fluids and Modified Version for Simultaneous Measurement of Total Antioxidant Power and Ascorbic Acid Concentration. Methods in Enzymology, 299, 15-27. 
[21] Mosmuller, E.W.J., Van Heemst, J.D.H., Van Delden, C.V., Franssen, M.C.R. and Engbersen, J.F.J. (1992) A New Spectrophotometric Method for the Detection of Lipase Activity Using 2,4-Dinitrophenyl Butyrate as a Substrate. Biocatalysis and Biotransformation, 5, 279-287. https://doi.org/10.3109/10242429209014874

[22] Kim, J.S., Kwon, C.S. and Son, K.H. (2000) Inhibition of Alpha-Glucosidase and Amylase by Luteolin, a Flavonoid. Bioscience, Biotechnology, and Biochemistry, 64, 2458-2461. https://doi.org/10.1271/bbb.64.2458

[23] Apostolidis, E., Kwon, Y.-I. and Shetty, K. (2007) Inhibitory Potential of Herb, Fruit, and Fungal-Enriched Cheese against Key Enzymes Linked to Type 2 Diabetes and Hypertension. Innovative Food Science \& Emerging Technologies, 8, 46-54. https://doi.org/10.1016/j.ifset.2006.06.001

[24] Hollingsworth, P. (1997) Mainstreaming Healthy Foods. Food Technology, 51, 55-58.

[25] Nair, S., Nagar, R. and Gupta, R. (1998) Antioxidant Phenolics and Flavonoids in Common Indian Foods. The Journal of the Association of Physicians of India, 46, 708-710.

[26] Suhaj, M. (2006) Spice Antioxidants Isolation and Their Antiradical Activity: A Review. Journal of Food Composition and Analysis, 19, 531-537. https://doi.org/10.1016/j.jfca.2004.11.005

[27] Chaieb, K., Hajlaoui, H., Zmantar, T., Kahla-Nakbi, A.B., Rouabhia, M., Mahdouani, K. and Bakhrouf, A. (2007) The Chemical Composition and Biological Activity of Clove Essential Oil, Eugenia caryophyllata (Syzigium aromaticum L. Myrtaceae): A Short Review. Phytotherapy Research, 21, 501-506. https://doi.org/10.1002/ptr.2124

[28] Kalra, S. (2014) Alpha Glucosidase Inhibitors. JPMA. The Journal of the Pakistan Medical Association, 64, 474-476.

[29] Cazzola, R., Camerotto, C. and Cestaro, B. (2011) Anti-Oxidant, Anti-Glycant, and Inhibitory Activity against $\alpha$-Amylase and $\alpha$-Glucosidase of Selected Spices and $\mathrm{Cu}$ linary Herbs. International Journal of Food Sciences and Nutrition, 62, 175-184. https://doi.org/10.3109/09637486.2010.529068

[30] Chirumbolo, S. (2012) Plant Phytochemicals as New Potential Drugs for Immune Disorders and Cancer Therapy: Really a Promising Path? Journal of the Science of Food and Agriculture, 92, 1573-1577. https://doi.org/10.1002/jsfa.5670

[31] Birari, R.B. and Bhutani, K.K. (2007) Pancreatic Lipase Inhibitors from Natural Sources: Unexplored Potential. Drug Discovery Today, 12, 879-889.

https://doi.org/10.1016/j.drudis.2007.07.024 